\title{
University Managerialism and Scientific Publication
}

\author{
Fernando Ampudia de Haro \\ UNIVERSIDADE EUROPEIA / CIES - INSTITUTO UNIVERSITÁRIO DE LISBOA \\ fernando.ampudia/Auniversidadeeuropeia.pt \\ Received: 24/04/2018 \\ Accepted: 29/11/2018
}

\begin{abstract}
The paper sets out a general approach to university Managerialism and its links with the scientific publication system. In an academic context, techniques and practices bearing on the management field include a specific view on why and how to publish, as well as what ends publication should serve. This work explores the discourse legitimising that view and reconstructs the behavioural and emotional human archetype it enshrines. The empirical materials used are the handbooks, guides and presentations targeting university staff with a view to boosting their publishing output. The paper ends with a critical assessment of the discourse and the archetype's implications in semi-peripheral academic contexts in terms of the production of scientific knowledge.

Keywords: impact factor, academic career, Norbert Elias, Neo-Liberalism, EC3metrics, Emerald, Springer.
\end{abstract}

Corresponding author: Fernando Ampudia de Haro, Centro de Investigação e Estudos de Sociologia (CIES-IUL) do Instituto Universitário de Lisboa. Ed. Sedas Nunes. Av. das Forças Armadas, 1649-026 Lisboa (Portugal).

Suggested citation: Ampudia de Haro, F. (2019): University Managerialism and Scientific Publication. Debats. Journal on Culture, Power and Society, 4, 43-57. DOI: http://doi.org/10.28939/iam.debats-en.2019-4

\section{INTRODUCTION}

Managing is what managers do. Management is a mix of knowledge and techniques that one applies to one's activities. The knowledge and techniques are usually acquired by taking a higher degree in Business or one of the many MBAs (Master of Business Administration) offered by universities and business schools. The curriculums cover various subjects: Accountancy, Finance, Business Strategy, Human Resources, Law, Marketing, Organisational Theory, Information Systems, and so on. Nevertheless, this pen picture would be incomplete without mentioning the mentality of those who generally run organisations. Management is not a neutral exercise (or a 'technical matter', as some might argue).
It includes values and norms regarding the behaviour and attitudes that are needed and desired in those staffing companies. We give those occupying posts of responsibility and who wield power a variety of names (managers, directors, executives, middle managers, coordinators). These individuals are privileged dispensers of a discourse that not only embodies said values and norms but which also dictates how the organisation and its members should be run. Management therefore inevitably implies individual subjectivism that is bound up with the foregoing technical requirements.

This paper takes up the issue to analyse a specific kind of subjectivism stemming from the managerial- 
ist model found in universities and its manifestation in the production of scholarly publications. Today's "publish or perish" dynamic puts a great deal of pressure on those who teach and research at universities. The policy is rammed home by the Impact Factor (IF) for scholarly journals and international indexing of publications by myriad evaluation criteria, and measurements of professional performance and promotion. The purpose of these pages is to explore the publishing side of this archetypal teacher-researcher in relation to the managerialist mind set found in university administration.

To this end, the first part of this paper will characterise the managerialist phenomenon, identifying its main areas of influence to illustrate how it manifests itself in the university setting and what repercussions it has for scholarly publishing.

The second part of the paper focuses on the archetype of teacher-researchers spawned by university Managerialism. This archetype can be reconstructed from the teaching materials offered to teacher-researchers to boost their scientific output, which necessarily entails changing their publishing behaviour. Nowadays, it is common to find universities offering courses, workshops, and seminars to teach faculty how to publish in so-called 'high-impact journals', and thereby tailor their publishing habits to fit the desired pattern.

I consider that such teaching materials offer a good source for analysing the kind of subjectivism demanded of teacher-researchers. Here, I employ an approach similar to that developed by Norbert Elias to analyse the codes of conduct employed throughout the civilising process, reconstructed from manuals on courtesy, etiquette, and manners (Elias, 1987). Thus the aim is to study the code used in the setting of scientific publication. This code can be reconstructed using the guides, texts, and presentations found in the aforementioned courses, workshops, and seminars. The choice of the material analysed is shaped by my professional experience of the subject matter. My academic career began in Spanish universities and I currently work in Portuguese ones. Accordingly, no inferences should be drawn as to the specificity or generalisability of the findings. That said, the material reveals a vision of scientific publication that is not confined to Spain or Portugal. Ambiguities and tensions regarding this vision are to be found in the academic communities of both countries.

Three dimensions are distinguished in analysing the aforementioned material. The first dimension bears on 'why', which is to say the general arguments justifying and legitimising the need to publish and what is considered 'the right way' of going about it. The second dimension bears on 'how', that is, the method to be employed in producing a study worthy of publication. The third dimension focuses on 'goals', covering the broader purpose of scientific publishing. In short, the analysis follows a simple 'question and answer' format. This approach breaks down the overall prescriptions of the training materials underpinning the behavioural and emotional code on scholarly publication.

The third part of the paper critically analyses said code. The archetypal teacher-researcher espoused by the code leads to certain scientific publication practices whose consequences are undesirable. These outcomes stem from the intellectual theft implied by treating research as a mainly individual activity and that is thus devoid of any socio-structural frame.

\section{MANAGERIALISM: CHARACTERISATION AND PRESENCE IN UNIVERSITIES}

Following Alonso and Fernández Rodríguez (2013), Managerialism is the ideology of those who wield power in organisations. It is the set of beliefs, ideas and values bearing on the intended effective governance of an organisation. Although the phenomenon is more often studied in the business field, it is not confined to this sphere and is applicable to any complex organisation (Fernández Rodríguez, 2007a). Managerialist ideology has historically been manifested through various kinds of discourse that have shifted with changes in the Capitalist system and in its accumulation cycles (Fernández Rodríguez, 2007b). These discourses take 
various forms (books and management manuals, the training given by universities and business schools, events, lectures, tutorials, talks), all of which are used to pass on the contents and guidelines of whatever happen to be the management models in vogue.

In general, the main tenets of Managerialism are:

1. Organisations, regardless of their purpose and nature, can be managed using the knowledge, procedures, and techniques provided by the Management Sciences (Klikauer, 2015).

2. Such knowledge, procedures, and techniques are legitimised by their suitability for ensuring organisational effectiveness, efficiency, competitiveness, sustainability, flexibility, resilience, and excellence, given that these are the desiderata commonly preached by organisations. That is to say, the legitimacy of this know-how lies in the extent to which it is capable of reaching these goals (Klikauer, 2015).

3. Organisational settings pose challenges and limitations that require the use of management know-how, procedures, and techniques. Management know-how gives these settings different features that stem from historic changes in Capitalist profitability cycles. At different junctures, these settings have been seen as ones that are: scientifically predictable and calculable (the Taylorist-Fordist Model); balanced and prosperous thanks to moderation through the Keynesian Social Pact (Human Relations Model); Dynamic and Flexible (the Japanese Differentiation and Quality Model). The model that currently holds sway is one that stresses dynamism, innovation, and lauds the ever-changing nature of the market and the uncertainty engendered by a fiercely competitive setting. It shuns stability and routine. This constant change is sold as an open door to endless opportunities spawned by uncertainty. There is talk of a global, networked 'Knowledge Economy'. This characterisation stems from a set of attributes that organisations set great store by: a pro-active, entrepreneurial attitude; leadership; innovation; cutting out red tape; teamwork; belonging to a corporate culture; boosting employability through the projects and opportunities an organisation offers its members (Chiapello and Fairclough, 2002; Alonso and Fernández, 2012, 2013).

4. Management knowledge, procedures, and techniques are mainly applied in business settings - it being understood that these are best for dealing with people and as a model of social relations. It is assumed that this management know-how is particularly effective in Free Market settings.

Managerialism's tenets are inevitably abstract. Their materialisation in a given organisation gives one a better idea of their scope. Bearing in mind the purpose of this paper, it is time to focus on universities and the managerialist vision found there so that one can deduce what approach to scientific output and publication has been adopted.

Universities' managerialist vision is based on the setting within which these institutions operate - one that is defined by the positive link between Science and Technology, and economic development. The importance of this link is highlighted by international bodies, such as the European Commission and the key role assigned to universities in reaching the goals set out in The Lisbon Strategy (CCE, 2005). Economic development fostering social progress is based on aligning knowledge with its industrial and economic application - that is to say, the soundness of the "knowledge-industry-market" sequence (De Angelis and Harvie, 2009; Santiago et al., 2013; Marugán and Cruces Aguilera, 2013).

In this setting and in keeping with this role, universities are seen as institutions that compete in a global market to attract students, teachers, and researchers. Those that are successful in this endeavour boost the economic value of the knowledge they produce, their academic reputations and hence their chances of getting funding. The end result is that they raise 
their market share, unlike their less successful competitors. The setting up of a European Higher Education Area under The Bologna Process begun in 1999 is an example of the mercantile approach to the university field. In such a setting, universities compete to attract students and seek convergence in qualifications in order to meet the demands of the job market, draw up learning quantification and certification schemes (European Credit Transfer and Accumulation System — ECTS) and seek academic and geographic mobility among all those institutions taking part.

Universities' financial and budgetary autonomy are key parts in this mercantile configuration. Given that universities are market agents, their viability cannot depend solely on State support. Their ability to successfully compete will provide access to new sources of funding (Lorenz, 2012; Hyde et al., 2013). The competitive dynamic fosters and requires performance measurement methods allowing comparisons to be drawn with other universities. Rankings stand out among these methods, in which institutions are ranked in order from best to worst, based on criteria such as: scientific output; the prestige of their faculty members; prizes; number of patents; public relevance; turnover; growth in the size of the student body, and so on. This auditing culture (Strathern, 2000) and its obsession with measurement are enshrined in Times Higher Education, which is produced by The Times newspaper group, and the Jiao Jong University Ranking (better known as 'The Shanghai Ranking'). These two rankings reflect the state of the Education Market and the relative positions of their participants. They guide students, faculty and researchers in their decision-making. In a nutshell, they are tools summarising information for those operating in the university market.

'Excellence' is the symbolic goal of all this competition yet it is hard to pin down. It is usually based on a hotchpotch of criteria such as: quality, distinction, reputation, the relevance of the knowledge produced. It is The Holy Grail of the institution's activities and any university worth its salt trots it out in all its public statements (Gómez and Jódar, 2013; Herzog et al.,
2015). Seen in this light, it is little wonder that universities have become a happy hunting ground for Managerialism. In the context of competition among institutions, the generation of one's own funds, putting a market price on knowledge, and battling for market share, management knowledge and practices are presented as being the best option for attaining these goals in an ever-changing, volatile setting. In other words, managerial knowledge and practices are passed off as vital for any university operating in The Knowledge Economy.

This brings in its train a highly specific notion of what academic duties are (Kehm and Teichler, 2013). Scholars are expected to: boost their output of papers in high-impact journals; run projects that attract funding and boost market reputation and value; lead teams; train future researchers; draw up activities for transferring know-how to the industrial and business sectors. While not all these demands may be made at the same time, it is not unusual for this to be the case. Ironically, as some authors have noted, faculty members are expected to be busy 'one-man bands' (Villasante, 2016). Although this is now the dominant discourse when one thinks of universities, teaching, and research, there are others that resist this bleak vision. This resistance involves conceiving of the university as a repository of knowledge, and of faculty members as fostering a critical, civic awareness of the world. Such ideas are clearly at odds with the managerialist orientation and other discourses uneasily cohabit with it, as one can appreciate in the self-presentation universities make on their web sites (Santiago et al., 2013), or in faculty members' practices (Anderson, 2008). Yet attempts to sweep such resistance aside cannot hide the managerialist demands made of individuals in terms of scientific output and publication:

1. A big part of the assessment of and scope for professional advancement depends on publishing in high-impact scientific journals as identified by Web of Science or Scopus. Space does not permit a detailed explanation of the rationale underlying these data bases (Ampudia de Haro, 2017) or 
the Impact Factor (Archambault and Larivière, 2009). For the purposes of our argument, one simply needs to bear in mind that indexing and the Impact Factor (IF) are seen as indicators of research quality and relevance. These indicators are used to measure research efforts and to take management, planning, and funding decisions on such activities (Fernández-Ríos and Rodríguez-Díaz, 2014).

2. These indicators are built up from bibliometric data and are an important factor in drawing up university rankings and classifications, which in turn are used to promote and convey universities' prestige.

3. Higher rankings also raise the likelihood that research will prove more profitable and thus boost the chances of gaining new resources to fuel this 'virtuous cycle'.

A discursive nexus is established between the global context of 'The Knowledge Economy', the mercantile value of science, efficient knowledge management, the Impact Factor, and scientific output as indicators of market quality and value. In this sequence, the managerialist approach determines what scientific output is relevant and which journals are important. This not only means intervening in scholars' publishing practices but also in their values. The end result is that academics' natures and judgement become grist to the keen competition among universities and the goals stemming from it.

\section{THE TEACHER-RESEARCH AS HIGH-IMPACT PUBLISHER}

There is an intellectual style and emotional prototype in managerialist academe. Several authors have covered this subject (Hicks and Potter, 1991; Burrows, 2012; Gómez and Jódar, 2013; Fernández-Ríos and Rodríguez-Díaz, 2014; Goyanes, 2015), whether through qualitative methodologies, theoretical contributions, or general reflection. The path explored in this paper is an examination of the prescriptive discourse on scientific publication, reconstructed using the training materials given to faculty members with a view to boosting their publications in high-impact journals. Said discourse determines the 'why' and 'how' of publication and what should be done with published papers. In other words, it attempts to both establish a publishing routine and to reshape the subjectivism of the individual so that he or she can be turned into a teacher-researcher-academic publisher.

The materials are used in seminars, conferences, courses, and workshops. They offer ideas, recommendations, and methods for boosting scientific productivity. Sometimes the materials are drawn from the main scientific publishing houses, which give training in collaboration with universities. On other occasions, they are provided by organisations specialising in scientific evaluation and bibliometric analysis. The selection I made of the materials is not systematic but rather reflects my professional experience. I have taken part as a student in various sessions of this kind and therefore have first-hand knowledge of the materials used. I would like to make these materials available to all readers. That is why I have chosen similar materials to those I was provided with but that are freely available over the Internet. Similarly, to show the cross-cutting nature of such materials, I combine sources published in Spain and in Portugal. In general, the scientific productivity discourse covering publication is trans-national in nature, although there may be local adaptations to specific academic cultures (Blagojevic and Yair, 2010).

The materials analysed are briefly described below:

- Cómo publicar en revistas científicas de impacto [How to Publish in High-Impact Scholarly Journals], by Daniel Torres-Salinas (2013), is a manual containing suggestions and recommendations for said purpose. The manual incorporates a set of activities developed by the EC3metrics company (which sprang from the EC3 research group Evaluación de la Ciencia y la Comunicación Científica [Evaluation of Science and Scientific Communication], Universidad de Granada). This company, as its web page shows, offers services covering: 
the evaluation of research; scientific publishing houses and journals; advice on requesting sabbatical years for research; bibliometric training; scientific communication.

- Informe APEI sobre publicación en revistas científicas [APEI Report on the Publication of Scientific Journals], by Tomàs Baiget and Daniel Torres-Salinas (2013), is also conceived as a manual on what to bear in mind when publishing in high-impact scientific journals.

- Three initiatives forming part of the training imparted by Universidade de Aveiro (Portugal) to authors and researchers. In this case, those leading the publication workshops are representatives of some of the main publishing houses for international scientific journals. One of these is Springer, imparting two sessions - $\mathrm{Pu}$ blishing Scientific Research (Hawkins, 2012) and Springer Updates: E-Books, journals and publishing tips (Alkema, 2015). The other is Emerald, with its Guía para publicar [Guide to Publishing] (Toffolo, 2013). Springer, Emerald, Taylor \& Francis, Sage, and Wiley-Blackwell between them publish no less than $66 \%$ of the papers listed in Web of Science, which is owned by the Thomson-Reuters Group. In 2013, and covering just Social Science publications, Emerald published $16.4 \%$ and Springer $7.1 \%$ of all papers, percentages 4.4 and 21.3 times greater than their respective shares in 1990 (Larivière et al., 2015). In both cases, we again find recommendations and instructions on publication in high-impact indexed journals, as well as a commercial plug on the two publishing houses' academic portfolios.

In reconstructing the code used in scientific publication, I pose the following three questions: (1) Why publish?; (2) How should one publish?; (3) What should one do with what has been published? As noted in the introduction to this paper, this approach is similar to that used by Norbert Elias in his work The Civilization Process. Taking this tack reveals the key points of the behavioural and subjectivism model sought for application in academe. Although this model is a salient feature, it is just another component of the academic framework within which teacher-researchers operate. Meeting the code's prescriptions does not only depend on an individual's hypothetical merits. Here, we need to consider the set of structural factors driving compliance, including: the conditions for and opportunities to pursue an academic career; the procedures for evaluating teaching and research activities (which are inevitably linked with said career); the hegemony of English and of theoretical models from the English-speaking world. As we shall see further on, subjectivism is not only shaped by a given code. Although it is not the main goal of this paper, socio-structural conditions should always feature in any explanation of subjectivism in the academic world.

\section{Why publish?}

Publishing is never understood in a general sense. Rather, it basically refers to publication in high-impact journals. Outside this frame, publication has another purpose, which has nothing to do with determining the author's quality or productivity. This is so because: "Most scientific policies and evaluation of scientific performance rest on JCR-listed journals (Journal Citation Report) and Thomson Reuters listed publications" (Torres-Salinas, 2013: 25).

Having clarified this point, two arguments can be made for such publishing. The first is that high-impact journals are associated with positive values. The second is that publishing in them does a researcher's career a power of good.

As to the first argument, the list of 'HI' (High Impact) journals is taken as an indicator of the quality of a publication and, by extension, of the quality of the papers appearing therein: "There can be no doubt that impact factor is taken as the yardstick of a journal's quality by many academic communities" (Hawkins, 2015: 27). This judgement arises from the competitive dynamics prevailing when it comes to scholarly publication. Put baldly, a researcher's stock is greatly boosted by publishing in top journals. 
This in turn spurs him to make more submissions, giving the journal editors a bigger pool from which to select outstanding papers. Competition thus acts as a qualitative filter (Torres-Salinas, 2013: 21). As to the second argument, the following quotation illustrates the positive dynamics set in motion by the publication of an HI paper, and that lead to printing of one's work in ever more prestigious journals:

[Publication in scholarly journals benefits both the researcher and the institution he works for. The researcher has a better career and will gain recognition as an expert in his field, which implies a virtuous circle of promotions, access to competitive examination and thesis tribunals, sitting on the editorial committees of scientific journals and congresses, gaining funding and staffing for his research group or lab, which in turn spawns new studies and publications in leading journals] (Baiget and Torres-Salinas, 2013: 9).

This 'virtuous circle' — on which Toffolo (2013: 13) and Hawkins (2012: 4) concur — provides a compelling set of reasons for publishing. From this standpoint, any reason given for not publishing in the charmed circle of high-impact journals is dismissed as inconsistent, no matter how reasonable it may be. Thus defending one's own language in the face of the growing sway of English; tackling local or national themes that international journals neither understand nor are willing to embrace; avoiding an endless wait between submitting a paper and receiving the evaluation; insisting that books and book chapters are more valuable than a paper in a high-impact journal are all arguments that are given short shrift (Torres-Salinas, 2013: 31-32). The managerialist response to such objections is a depressingly familiar one: "Change the focus; adapt to the international 'standard'; change your strategy; publish less overall and publish more in HI journals; change the subjects covered; Seek relevant issues in the field" (Torres-Salinas, 2013: 33).

\section{How should one publish?}

One should publish so as to maximise the positive effects of publication. These effects are initially linked with the article's appearance in a high-impact journal and the consequent benefits for the author in terms of recognition, prestige, and career advancement. To this end, one must join or set up teams with various researchers given that specialised division of labour and cross-review may boost one's publication output. The only point that needs to be decided beforehand is the order in which the authors will appear in the publication (Torres-Salinas, 2013: 37-38, 41).

One should also remember to use English because it is the international language of Science (Hawkins, 2012: 6), which means papers have to be reviewed by native speakers specialised in the field. Poor writing raises editors' hackles: “Journals simply hate badly-written papers and have a special loathing for those written by Spaniards" (Torres-Salinas, 2013: 73). Then comes the moment to choose the journal in which the paper is to appear. Given that the problem boils down to offsetting a tiny number of papers with publication in the highest-ranked journals, one needs to be very careful in placing one's bets (Toffolo, 2013: 19). Furthermore, one needs to take editorial advice and timing into account and never choose those journals whose impact factors are waning (Torres-Salinas, 2013: 48).

The choice of bibliographic sources also needs painstaking care. First of all, it has to be up to date and provide lots of scope for spawning citations, which in turn will boost the journal's impact index and the researcher's reputation (Hawkins, 2012: 14). The sources must be both relevant and appropriate. That is why one: "should avoid exotic citations of littleknown local authors"; "cite articles on the subject that have appeared in the chosen journal"; "not omit citations by one's competitors (for they may well be one's reviewers)"; "avoid lots of references to books, manuals, or textbooks" (Torres-Salinas, 2013: 61).

\section{What should one do with what has been published?}

Scientific Publication does not stop when a paper sees the light of day. That is because this marks the beginning of a process to make both the research results and the author better known. In other words, the idea is to raise the author's profile so that he can be seen as 
someone churning out research (Toffolo, 2013: 53-55). Discoverability is the buzz-word used to capture this idea (Alkema, 2015: 12), which basically means the author can be tracked down by any search engine. At the same time, discoverability is linked to how hard the author blows his own trumpet. Here, he needs to come up with initiatives to explain what he does and what he publishes. The recommended media tools for this thrilling task are: personal web pages; participation in blogs and social media (Facebook, Twitter, LinkedIn); uploading presentations used in classes and congresses to the Slideshare site; keeping one's Curriculum Vitae up to date on institutional web pages. At the same time, he should not overlook academic networks and it is recommended that he have profiles on ORCID, Google Scholar, Researcher ID, Scopus, and Academia.eu (Baiget and Torres-Salinas, 2013: 87-88). Last but not least, he needs to stay abreast of the reactions to his paper by following citations on the aforementioned academic networks, and keep an eye on its social repercussions by following the number of 'Likes' on Facebook and Twitter. In a nutshell, "one has to bear in mind that the container, wrapping, support, or presentation - that is to say, the formal aspects - are just as important as the content. Indeed, we do not dare say so but we are tempted to say such aspects are more important than the content" (Baiget and Torres-Salinas, 2013: 90).

The 'why, how, and what' of the matter not only lead to a given pattern of behaviour and decision-making but also require a specific kind of subjectivism and way of regulating it. In this respect, the adaptation made by Torres-Salinas (2013) of Stephen Covey's 1989 classic self-help Bible, The 7 Habits of Highly Effective People to come up with Los siete hábitos de las personas altamente efectivas [The Seven Habits of Highly Effective Researchers] is paradigmatic, clear and explicit:

The first three habits concern the researcher's private sphere: take a pro-active attitude instead of just hoping that "something will turn up" (Torres-Salinas, 2013: 10). This boils down to: (a) proposing articles, debates, and activities; (b) setting objectives and 'visualising' them so that they 'materialise'; (c) organising one's times and tasks through Covey's matrix, which distinguishes between the following categories: 'important', 'urgent', 'unimportant', and 'not urgent'.

The next three habits fall within the researcher's public sphere. The first involves adopting a 'win-win' attitude instead of trying to hog the limelight in the research group. Above all, "publication should be seen as a victory for the group" (Torres-Salinas, 2013: 11). The second requires "understanding and being understood", in which he recommends reviewing one's opinions and accepting alternative views. The third habit is exploiting synergies in the division of labour within the group. The last habit - 'sharpening the saw' - enshrines all six of the preceding ones. The expression is lifted from Covey's magnum opus and refers to an apocryphal story of a weary lumberjack who spends five hours hewing down trees but who refuses to sharpen his saw because it would break his rhythm (Covey, 2003: 176). The 'sharpening' metaphorically alludes to the need to constantly innovate within the four basic dimensions of human nature, namely: Physical; Spiritual; Mental; Socio-Emotional. Applying this folksy homily to the field of publication, the highly effective researcher 'sharpens his saw' by: keeping abreast of developments in his field; reading scientific papers; learning new methods, techniques, and languages (Torres-Salinas, 2013: 12). Taken as a whole, these recommendations constitute a fully-fledged programme for regulating researchers' behaviour when it comes to publishing scientific papers.

\section{CRITICISMS OF THE MODEL}

The prescriptive discourse on scientific publication reveals a model of the teacher-cum-researcher-cumpublisher that enshrines four key features: (1) strategic self-hetero-vigilance; (2) utilitarian publishing rationality; (3) intellectual ritualism; (4) publishing self-absorption.

1. 'Strategic self-hetero-vigilance' is based upon bibliometric indicators. Among these indicators, 
the impact factor of journals and the number of citations of one's paper allow one to calculate or estimate the relevance of both one's own and others' scientific output. This in turn lets one plan one's behaviour (Burrows, 2012; Berg et al., 2016) and exercise reflexive control over one's publishing habits - which is a prerequisite for accumulating scientific capital (Bourdieu, 2008). This should be seen as a synthesis of technical knowledge and intellectual authority, giving the fortunate soul acquiring such wisdom the ability to decide (vis-à-vis his peers) what is or is not a legitimate practice or object of study. Furthermore, it allows him to increase his room for manoeuvre in the regimented university world and to plan his assault on the commanding heights of academe. The scope for manoeuvre is greatly boosted when the 'virtuous publication cycle' kicks in. Put another way, the path beginning with the publication of a paper in a high-impact journal is a rose-strewn one, leading to promotion, competitive examination and thesis defence boards, publishing boards, funding and staffing, and to the publication of further papers to build a bulwark against one's competitors.

2. 'Utilitarian publishing rationality' refers to maximising one's publication efforts. One can see it as an imperative that can be summed up as ensuring that one's actions boost the impact of one's publications. Such maximisation involves being able to estimate or even calculate the impact produced by publication, or in the vivid expression used by Alvesson (2012), the adoption of an 'ROIsearch mind set' (the term being a blend of the acronym 'ROI' (Return on Investment) - used in the business world and 'research'). The term alludes to the 'why' and 'how' of publication and to the fate of what has been published. The purpose here is to decide the extent to which the researcher's investment in time and effort yields profitable returns.
Yet this kind of mind set contradicts certain institutional postulates characterising the classic scientific ethos: communalism; universalism; disinterest (McFarlane and Cheng, 2008). Briefly, Communalism means scientific knowledge as a common good that is freely accessible by the whole community. Universalism enshrines the notion that a researcher (regardless of his cultural and social background) can contribute to knowledge creation through the assiduous application of the scientific approach and scientific methods. Last, Disinterest is the suppression of personal preferences in validating or rejecting the conclusions of a research paper, basing one's judgement purely on the application of scientific methods and rigour. In stark contrast to this triad of values, 'utilitarian publication rationality' nurtures an 'ROIsearch' (sic) mind set, individualism, particularism, and self-interest. Individualism is linked to powerful incentives - reputation, recognition, career advancement, funding - that drive maximisation of the personal impact of publications against a background of fierce competition. It thus challenges the notion and value that knowledge belongs to everyone and is thus the sole preserve of no one. Particularism is linked to the specific conditions of those researchers who, for geographical, linguistic, or material reasons, occupy the commanding heights in the world flow of scientific publications. In other words, the point of departure for those either publishing or wishing to publish varies greatly - an issue I will cover in greater detail in the next section. Last, Interest refers to the opportunistic or 'strategic' choice of themes, methods, and approaches to maximise the impact of publications - something that leads to a spate of fashionable 'burning issues' and endless 'me-too' citations in which the goal is to jump on a bandwagon (Espeland and Sauder, 2007; Fernández-Ríos and Rodríguez-Díaz, 2014).

3. Intellectual ritualism refers to the standardisation associated with scientific publication. The 'why', 'how', and 'what to do with outputs' aspects of scholarly publication cover a highly restrictive, 
uniform set of procedures whose sole purpose is to get papers into high-impact journals. This carries the obvious risk of spawning mass production of papers whose structure, drafting, language, focus, method, and theme are most likely to favour publication in such journals. Here, one can speak of ritualism insofar as said standardisation ignores what should be the primary purpose of publication (namely, communicating knowledge) and instead fosters sausage-machine production of 'me too' scientific papers.

4. Publishing self-absorption bears on the number of publications and citations as a yardstick of scientific distinction. Such activities are accompanied by a host of steps whose purpose is none other than to highlight the researcher and to propel the number of references to his oeuvre to dizzying heights. The peril here is that the researcher will be turned into little more than a PR specialist adept at banging his own drum and at puffing up the importance of his work. This over-the-top personal promotion nurtures the kind of 'super-star mentality' that is clearly discernible in the individual marketing initiatives peddled to researchers (Alvesson, 2012).

The aforementioned four dimensions make up a model of the teacher-researcher-publisher that draws on specific individual abilities for maximising publication opportunities, self-promotion, and self-evaluation. At the same time, characterisation of the academic setting as competitive and in which the rules are the same for everyone leads to a kind of 'reciprocal vigilance'. This is where hetero-evaluation comes into play, which is to say the external monitoring of publication behaviour and snap judgements and opinions on the scientific and reputation value of the output. The accent is therefore placed on the individual and his willingness to accept and cultivate the prescribed pattern of scientific publication.

Nevertheless, such a model betrays the elements I consider vital for maintaining an informed debate on scientific publication. Approaching the issue from the narrow perspective of the individual researcher means sweeping aside the socio-structural framework within which research takes place. The recommended mix of individual action and pro-active research has a lot to do with the position various countries and their respective scientific systems occupy in the world academic pecking-order (Alatas, 2003; Beigel, 2013). In this scheme of things, the system in The Iberian Peninsula is clearly lower down the pecking order, which is headed by The United States and The United Kingdom, and with The Netherlands and Germany well-placed in some branches of knowledge (Heilbron, 2014). Changing the analogy, the US and UK are at the centre of a system that pushes other countries to the edges.

At the centre:

a. the knowledge produced is linked to questions and issues bearing on central societies, thus the English-speaking world's theoretical models and traditions are given priority (Blagojevic and Yair, 2010);

b. universities and research centres forge very close relationships with the main scientific publishers;

c. English is the hegemonic language in the field of scientific publication and communication (Hamel, 2007);

d. one finds the entities drawing up the main impact indicators, university rankings, and indexing systems.

On the periphery:

a. there is a process of mediation and channelling of knowledge produced at the centre to adapt it to the languages used in the periphery (Bennett, 2014a);

b. there are movements emulating those at the centre, replicating and internationalising their 
publication patterns. The attraction exercised by the centre helps legitimise the teacher-researcher-publisher model. One of the main drivers of this emulation is the wholesale swallowing of the theoretical models and traditions found at the centre. As a result, local models and traditions are pushed into the background and are dismissed as little more than quaint irrelevances;

c. there are also movements that are repelled by and distance themselves from the centre. This has to do with the precarious position of peripheral universities and research centres compared with those at the centre. Language barriers only make things worse because money has to be spent on translation, shrinking the chances of getting research funding. Here, one should also recall that the themes and objects researched bear on the national and/or local setting and are thus not easily 'internationalised'. The problem becomes even more acute when 'internationalisation' is interpreted through the blinkered view of the English-speaking world (Blagojevic and Yar, 2010).

The prescriptive discourse on scientific publication tells us: (1) to adapt to the 'international standard'; (2) to maximise impact; (3) of the wonders of the 'virtuous cycle' to be found in publication and selfpromotion. Here, the discourse links the need to be pro-active and effective, which only blinds us to the socio-structural aspect of research publication (Ampudia de Haro, 2017). Including this aspect makes one wonder whether adopting the above discourse, practices, and publication model will do anything to ease tensions between the centre and the periphery. Even more importantly, what is passed off as a global competition on 'a level playing-field' is anything but. The fact is that the game is rigged, favouring a few who, moreover, are in a position to influence the rules (Meriläinen, 2008). In both cases, I consider that the model will do nothing to narrow the gulf between the centre and the periphery, or to foster fair competition. That is because its prescriptions overlook the socio-structural nature of research and focus excessively on the individual.

\section{CONCLUSIONS}

From the Neo-Foucauldian view of governance (Rose and Miller, 1992; De Marinis, 1999), taking an individual-based approach leads to a political rationale that permeates this publication model. Here, 'political rationale' alludes to a set of goals sought by those wielding power, to the principles legitimising that power, and the concept of the nature of the individuals so governed. In this case, it is a Neo-Liberal creed that tries to align goals with the supposed capacity for self-governance enjoyed by the individual as an autonomous being (Hyndess, 1997).

If we apply this scheme to the subject of this paper, one can readily identify the goals sought by managerialist governance in both the university and scientific publishing spheres. Against a background of competition, the quest for excellence is based on financial assessments of knowledge and the return on investment regarding reputation, gaining market share, and attracting funding and other resources. Following this line of reasoning, publication is one of the tools serving such ends. However, one should recall that it is a highly idiosyncratic way of looking at publication and the behaviour it entails. While we may assume that individuals are autonomous, managerialist governance aims and publication training clearly condition this autonomy. From that point onwards, although a researcher may act autonomously, he will nevertheless have accepted the precept underlying the offer, inextricably linking it with the prospect of maintaining or advancing his career. Turning down the offer will be construed as an unwillingness to adapt, an excuse, a refusal to accept personal and/or career development, and in general, as 'the wrong attitude'. Seen like this, the Neo-Liberal rationale for this model of publication wholly overlooks the socio-structural aspect of the phenomenon and places most of the burden on individual initiative.

Such an approach dooms many researchers seeking publication to endless frustration. Yet how could this be otherwise when the recommended behaviour patterns presuppose sufficient resources (but that are 
seldom available in the real world and then only to the favoured few)? Bennett (2014b) uses an ironic and apt phrase to describe this situation - "Butler Syndrome". Here, he alludes to identification with a hypothetical upper class, in this case represented by 'the centre'. This identification provides a veneer of academic and scientific respectability vis-à-vis a supposed lower class, represented by the periphery. On the one hand, there is a desire and plan to join the centre - something that would yield the researcher scientific capital, legitimacy, access to science management, and financial and reputational advantages in academe. On the other hand, there are the structural hurdles: less funding and serious organisational shortcomings, working in languages other than English (Cabral, 2007), and the fact that part of the research agenda covers local and/ or national themes (here, the Social Sciences make little sense unless they are relevant to local society). All of these hurdles make it hard to square academic publishing with the notion of 'internationalisation' employed in the English-speaking world.

There are alternatives to the Neo-Liberal rationale that recognise both socio-structural limitations and their own limitations. To cite those I am most familiar with: Open Access Publishing (Sádaba Rodríguez, 2014); the challenge to high-impact journals as a criterion for evaluation, funding, contracting, and career advancement - a critical position enshrined in the San Francisco Declaration on Research Assessment (DORA, 2013); moderation in the use of present schemes - recommended in The Leiden Manifest; the open reflection made by the Indocentia group on universities and the system for evaluating teaching staff (Fernández-Savater, 2016). None of these belittle scientific publication but neither do they leave evaluation of faculty quality at the mercy of supposedly objective bibliometric methods. Eugene Garfield, who is often attributed with giving birth to impact factors, says the following of his brainchild:

The use of impact factors to evaluate people has inherent dangers. In an ideal world, the evaluators would read each paper and come up with their own views (...) Most people do not have time to read all relevant papers and even if they did, their views would be condemned in the commentaries of those reading their papers (Garfield, 2006: 93).

Regarding inherent dangers, I believe that the archetype of the teacher-researcher-publisher and the intellectual theft that it is party to illustrate these perils. We live in an imperfect world but that is no excuse for not doing a great deal better. Debating the NeoLiberal rationale governing managerialist discourse and finding ways to tackle structural inequalities and shortcomings could improve things no end. Here, I would take issue with Garfield and argue that any alternative programme needs to be based on a simple but ambitious premise. It is this, that researchers should have the time and the will to read and then be able to decide what is relevant and what is not.

\section{BIBLIOGRAPHIC REFERENCES}

\section{Primary Sources}

Alkema, D. (2015). Springer Updates. E-books, journals and publishing tips. Portugal: Universidade de Aveiro, training session given on the 7th of May 2015. En http://portal.doc.ua.pt/formacao/springer_D.pdf (accessed on the 4th of April 2017).

Baiget, T. and Torres-Salinas, D. (2013). Informe APEI sobre publicación en revistas científicas. Informe APEI 7. Gijón: Asociación Profesional de Especialistas en Información. En www.apei.es/wp-content/uploads/2013/11/ InformeAPEI-Publicacionescientificas.pdf (accessed on the 4th of April 2017).

Covey, S. (2003). Los 7 hábitos de la gente altamente efectiva: la revolución ética en la vicia cotidiana y en la empresa. Buenos Aires: Paidós. 
Hawkins, E. (2012). Publishing Scientific Research. Portugal: Universidade de Aveiro, training session given on the 17th of April 2012. www.ua.pt/sbidm/biblioteca/PageText.aspx?id=15298 (accessed on the 4th of April 2017).

Toffolo, L. (2013). Guía para publicar. GCP-Guide to getting publishing. Portugal: Universidade de Aveiro, training session given on the 17th of October 2013. www.ua.pt/sbidm/biblioteca/PageText.aspx?id=15298 (accessed on the 4th of April 2017).

Torres-Salinas, D. (2013). Cómo publicar en revistas científicas de impacto: consejos y reglas sobre publicación científica (4 $4^{\mathrm{a}}$ ed.). Granada: EC3metrics. https://ec3metrics.com/repositorio (accessed on the 4th of April 2017).

\section{Secondary Sources}

Alatas, S. F. (2003). Academic Dependency and the Global Division of Labour in Social Sciences. Current Sociology, 51(6), 599-613.

Alonso, L. E. and Fernández Rodríguez, C. J. (2012). El nuevo debate sobre el gerencialismo. ¿Innovación creativa o maquiavelismo financiero? En L. E. Alonso y C. J. Rodríguez (eds.), La financiarización de las relaciones salariales. Una perspectiva internacional (pp. 104-126). Madrid: Los libros de la Catarata.

Alonso, L. E. and Fernández Rodríguez, C. J. (2013). Los discursos del management. Una perspectiva crítica. Lan Harremanak. Revista de Relaciones Laborales, 28, 42-69.

Alvesson, M. (2012). Do we have something to say? From re-search to roi-search and back again. Organization, 20(1), pp. 79-90. DOI: $10.1177 / 1350508412460996$

Ampudia de Haro, F. (2017). O impacto de (não) ter impacto: Para uma sociologia crítica das publicações científicas. Revista Crítica de Ciências Sociais, 113, 83-106. DOI: 10.4000/rccs.6659

Anderson, G. (2008). Mapping Academic Resistance in the Managerial University. Organization, 15(2), 251-270. DOI: $10.1177 / 1350508407086583$

Archambault, E. y Larivière, V. (2009). History of the Journal Impact Factor: Contingencies and Consequences. Scientometrics, 79(3), 635-649.

Blagojevic, M. and Yair, G. (2010). The Catch 22 Syndrome of Social Scientists in the Semiperiphery. Exploratory Sociological Observations. Sociologija, 52(4), 337-358.

Beigel, F. (2013). El sistema académico mundial y las perspectivas del conocimiento producido en la periferia. Pensamiento Universitario, 15, 15-34.

Bennett, K. (2014a). Introduction. The Political and Economic Infraestructure of Academic Practice. The 'Semiperiphery' as a Category for Social and Linguistic Analysis. En K. Bennett (ed.). The Semiperiphery of Academic Writing. Discourses, Communities and Practices (pp. 1-10). London: Palgrave MacMillan.

Bennett, K. (2014b). The "Butler" Syndrome: Academic Culture on the Semiperiphery. Revista Canaria de Estudios Ingleses, 69, 155-171.

Berg, L. D., Huijbens, E. H. y Larsen, H. G. (2016). Producing Anxiety in the Neoliberal University. The Canadian Geographer, 60(2), 168-180.

Bourdieu, P. (2008). Homo Academicus. Buenos Aires: Siglo XXI.

Burrows, R. (2012). Living with the h-index? Metric Assemblages in the Contemporary Academia. The Sociological Review, 60(2), 355-372.

Cabral, J. (2007). Língua e hegemonia nas ciências sociais. Análise Social, 182, 233-237.

CCE (2005). Movilizar el capital intelectual de Europa: crear las condiciones necesarias para que las universidades puedan contribuir plenamente a la estrategia de Lisboa. Brussels: Comisión de las Comunidades Europeas (CCE).

Chiapello, E. and Fairclough, N. (2002). Understanding the new management ideology: a transdiciplinary contribution fron critical discourse and new sociology of capitalism. Discourse \& Society, 13, 185-208.

De Angelis, M. and Harvie, D. (2009). Cognitive Capitalism and the Rat Race: How Capital Measures Immaterial Labour in British Universities. Historical Materialism, 17(3), 3-30.

De Marinis, P. (1999). Gobierno, gubernamentalidad, Foucault y los anglofoucaltianos (o un ensayo sobre la racionalidad política del neoliberalismo), in R. Ramos y F. García Selgas (eds.), Globalización, riesgo, reflexividad. Tres temas de la teoría social contemporánea (pp. 73-103). Madrid: Centro de Investigaciones Sociológicas.

DORA (2013). Declaration on Research Assessment (DORA), Proposal for Thomson Reuters to Modify the Journal Impact Factor. https://sfdora.org/read (accessed on the 1st of April 2019).

Elias, N. (1987). El proceso de la civilización. Madrid/Mexico: Fondo de Cultura Económica. 
Espeland, W. N. and Sauder, M. (2007). Rankings \& Reactivity. How Public Measures Recreate Social World's. American Journal of Sociology, 113(1), 1-40.

Fernández-Ríos, L. and Rodríguez-Díaz, J. (2014). The Impact Factor Style of Thinking. A New Theoretical Framework. International Journal of Clinical and Health Psychology, 14, 154-160.

Fernández Rodríguez, C. J. (ed.) (2007a). Vigilar y organizar. Una introducción a los Cultural Management Studies. Madrid: Siglo XXI.

Fernández Rodríguez, C. J. (ed.) (2007b). El discurso del management: tiempo y narración. Madrid: Centro de Investigaciones Sociológicas.

Fernández-Savater (2016). Disciplinar la investigación, devaluar la docencia: cuando la Universidad se vuelve empresa. El Diario. http://www.eldiario.es/interferencias/Disciplinar-investigacion-devaluar-docenciaUniversidad_6_486161402.html (accessed on the 5th of April 2017).

Garfield, E. (2006). The History and Meaning of the Journal Impact Factor. The Journal of the American Medical Association, 295(1), 90-93.

Gómez, L. and Jódar, F. (2013). Ética y política en la universidad española: la evaluación de la investigación como tecnología de la subjetividad. Athenea Digital. Revista de Pensamiento e Investigación Social, 13(1), 81-98. DOI:http://dx.doi.org/10.5565/rev/athenead/v13n1.1169

Goyanes, M. (2015). Hacia una investigación estandarizada. Observatorio (OBS) Journal, 9(3), 85-99. DOI: http:// dx.doi.org/10.7458/obs932015826

Hamel, R. E. (2007). The Dominance of English in the International Scientific Periodical Literature and the Future of Language Use in Science. AILA Review, 20, 53-71.

Heilbron, J. (2014). The Social Sciences as an Emerging Global Field. Current Sociology, 62(5), 685-703.

Herzog, B., Pecourt, J. and Hernández i Dobon, F. (2015). La dialéctica de la excelencia académica: de la evaluación a la medición de la actividad científica. Arxius de sociologia, 32, 69-82.

Hicks, D. and Potter, J. (1991). Sociology of Scientific Knowledge: A Reflexive Citation Analysis or Science Disciplines and Disciplining Science. Special Studies of Science, 23(3), 459-501.

Hicks, D., Wouters, P., Waltman, L., Ricjke, S. and Rafols, I. (2015). Bibliometrics: The Leiden Manifesto for research metrics. Nature, 520, 429-431.

Hyde, A., Clarke, M. andy Drennan, J. (2013). The changing role of academics and the rise of managerialism. En B. M. Kehm y U. Teichler (eds.), The Academic Profession in Europe: New Tasks and Challenges (pp. 39-52). Heidelberg/ London/New York: Springer.

Hyndess, B. (1997). Disertaciones sobre el poder. De Hobbes a Foucault. Madrid: Talasa.

Kehm, B. M. and U. Teichler, U. (eds.) (2013). The Academic Profession in Europe: New Tasks and Challenges. Heidelberg/ London/New York: Springer.

Klikauer, T. (2015). What is Managerialism? Critical Sociology, 41(7-8), 1103-1119.

Larivière, V., Haustein, S. and Mongeon, P. (2015). The Oligopoly of Academic Publishers in the Digital Era. PLoS ONE, 10(6). En http://dx.doi.org/10.1371/journal.pone.0127502

Marugán Pintos, B. and Cruces Aguilera, J. (2013). Fragmentación y precariedad en la Universidad. Sociología del trabajo, 78, 10-34.

Meriläinen, S., Tienari, J., Thomas, R. and Davies, A. (2008). Hegemonic academic practices: experiences of publishing from the periphery. Organization, 15(4), 584-597. DOI: $10.1177 / 1350508408091008$

McFarlane, B. and Cheng, M. (2008). Communism, Universalism and Disinteredness: Re-examining Contemporary Support Academics for Merton's Scientific Norms. Journal of Academic Ethics, 6(1), 67-78.

Rose, N. and Miller, P. (1992). Political Power beyond the State: problematics of government. The British Journal of Sociology, 43(2), 173-205.

Sádaba Rodíguez, I. (2014). El acceso abierto en ciencias sociales: notas sociológicas sobre publicaciones, comunidades y campos. Argumentos de Razón Técnica, 17, 93-113.

Santiago, R., Carvalho, T. and Ferreira, A. (2013). As universidades portuguesas na senda da investigação empreendedora: onde estão as diferenças? Análise Social, 208, 594-620.

Strathern, M. (ed.) (2000). Audit Cultures. Anthropological studies in accountability, ethics and the academy. London/ New York: Routledge. 
Villasante, M. (2016). El profesor orquesta: Un modelo que lastra a la universidad española. El Mundo. http://www. elmundo.es/f5/campus/2016/12/21/585999eee2704e98698b45fc.html (accessed on the 4th of April 2017).

\section{BIOGRAPHICAL NOTE}

Fernando Ampudia de Haro graduated in Sociology (1998) and was awarded a PhD in the same subject (2004) by Universidad Complutense (Madrid) [UAM]. He took a Master Degree in Social Economics and Solidarity at ISCTEInstituto Universitario de Lisboa (2016). Ampudia de Haro received an Extraordinary Prize from Universidad Complutense [UC] for his PhD thesis La civilización del comportamiento: buenos modales y civilidad en España desde la Edad Media hasta la nuestros días [Behavioural Civilisation: Good Manners and Civility in Spain from The Middle Ages to Today].

Post-Doctoral Research Scholarship from Fundação para a Ciência e a Tecnologia [Science \& Technology Foundation] (FTC) (2006-2012) at The Institute of Contemporary History (IHC-Universidade Nova de Lisboa). He combines research activities with teaching at universities in Spain and Portugal.

His publications cover various fields: Historical Sociology; Politics; Emotions; Culture; Economics. His main fields of research are: Civilising Processes; Studies on Governance; Social Behavioural Models and Emotions. 